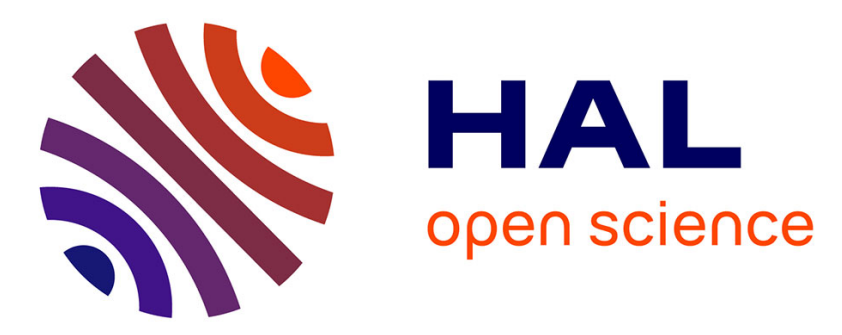

\title{
Experimental study on the swelling behaviour of bentonite/claystone mixture
}

Qiong Wang, Anh Minh A.M. Tang, Yu-Jun Cui, Pierre Delage, Behrouz Gatmiri

\section{- To cite this version:}

Qiong Wang, Anh Minh A.M. Tang, Yu-Jun Cui, Pierre Delage, Behrouz Gatmiri. Experimental study on the swelling behaviour of bentonite/claystone mixture. Engineering Geology, 2012, 124, pp.59-66. 10.1016/j.engeo.2011.10.003 . hal-00655761

\section{HAL Id: hal-00655761 \\ https://hal-enpc.archives-ouvertes.fr/hal-00655761}

Submitted on 2 Jan 2012

HAL is a multi-disciplinary open access archive for the deposit and dissemination of scientific research documents, whether they are published or not. The documents may come from teaching and research institutions in France or abroad, or from public or private research centers.
L'archive ouverte pluridisciplinaire HAL, est destinée au dépôt et à la diffusion de documents scientifiques de niveau recherche, publiés ou non, émanant des établissements d'enseignement et de recherche français ou étrangers, des laboratoires publics ou privés. 
${ }^{1}$ Ecole des Ponts ParisTech, UR Navier/CERMES

${ }^{2}$ ANDRA, France

8

Corresponding author:

Prof. Yu-Jun CUI

11 Ecole des Ponts ParisTech

12 6-8 av. Blaise Pascal, Cité Descartes, Champs-sur-Marne

13 F-77455 MARNE LA VALLEE

14 France

15

16 Telephone : +33164153550

17 Fax : +33 164153562

18 E-mail : yujun.cui@enpc.fr 


\begin{abstract}
A mixture of the MX80 bentonite and the Callovo-Oxfordian (COx) claystone were investigated by carrying out a series of experiments including determination of the swelling pressure of compacted samples by constant-volume method, pre-swell method, zero-swell method and swell-consolidation method. Distilled water, synthetic water and humidity controlled vapour were employed for hydration. Results show that upon wetting the swelling pressure increases with decreasing suction; however, there are no obvious effects of synthetic water chemistry and hydration procedure on the swelling behaviour in both short and long terms. For the same initial dry density, the swelling pressure decreases with increasing pre-swell strain; whereas there is a well defined logarithmic relation between the swelling pressure and final dry density of the sample regardless of the initial dry densities and the experimental methods. It was also found that swelling pressure depends on the loading-wetting conditions as a consequence of the different microstructure changes occurred in different conditions. Furthermore, it was attempted to elaborate a general relationship between the swelling pressure and the final dry density for various reference bentonites.
\end{abstract}

Keywords: bentonite/claystone mixture; swelling pressure; water chemistry effect; long term behaviour; final density; correlation.

\title{
1 INTRODUCTION
}

Deep geological repository is being considered for high-level radioactive waste (HLW) in several countries such as China, Belgium, France, Germany, Japan, Sweden, etc. In most cases, compacted bentonite-based materials are chosen as sealing/buffer materials thanks to their low permeability, high swelling and high radionuclide retardation capacities (Pusch, 1979; Yong et al., 1986; Villar et al., 2008).

Once the repository is closed and local groundwater conditions are re-established, the water in the host rock formation will move to the repository. The bentonite-based material absorbs water and swells, filling the technical voids as the gaps between the bentonite bricks themselves, between the canister and the bricks, between bricks and the host rock, as well as the fractures in the host rock due to excavation. After that, the subsequent swelling is restrained by the host rock and swelling pressure develops. From a mechanical point of view, in order to ensure the stability of the system, the swelling pressure must be lower than the in situ minor stress: $7 \mathrm{MPa}$ in the Underground Research Laboratory (URL) of Bure site, France (Delege et al., 2010; Tang et al., 2011a); 3-4 MPa at Tournemire site, France (Barnichon et al., 2009) and 4-5 MPa at Mol site, Belgium ( $\mathrm{Li}$ et al., 2009), etc. As the compacted bentonite-based material is a key component of a repository system, it governs the overall behaviour of the whole system. Hence, a proper understanding of how the compacted bentonite-based material behaves during hydration process is essential for 
the assessment of the short and long term performance of the repository system.

The behavior of compacted bentonite-based material upon wetting has been widely investigated, in terms of swelling properties (Pusch, 1982; Komine and Ogata, 1994, 2003, 2004a; Delage et al., 1998; Agus and Schanz, 2005; Komine et al., 2009); hydraulic behaviour under saturated state (Kenney et al., 1992; Dixon et al., 1999; Komine, 2004b;) and unsaturated state (Borgesson et al., 1985, 2001; Kröhn, 2003; Lemaire el al., 2004; Loiseau et al., 2002; Cui et al., 2008). There are also many studies on the effect of temperature (Komine and Ogata, 1998; Romero et al., 2001; Villar and Lloret, 2004; Tang et al., 2005; Tang et al., 2007; Tang et al., 2008a; Tang and Cui, 2009) and water chemistry of the saturating fluid (Pusch 2001a, Karland et al., 2005; Suzuki et al., 2005; Komine et al., 2009) on the hydro-mechanical (HM) behaviour.

For the swelling properties, it has been found that the swelling pressure determined in the laboratory can be affected by the experimental methods (Sridharan et al., 1986; Tang el al., 2011b). Normally, different methods give different values of swelling pressure due to the difference in the loading and wetting conditions in each method (Abdullah et al., 1998, 1999). In addition, the swelling properties depend on the initial dry density and water content of the soil specimen. The higher the initial dry density, the higher the swelling pressure or the higher the swelling strain; the swelling strain decreases with increasing initial water content, but the swelling pressure seems not to be affected by the initial water content (Komine et al., 1994; Villar et al., 2008). The swelling properties can be also affected by the chemical composition of the saturating fluid: the swelling capacity of the bentonite decreases with the increase in salinity of saturating fluid, although this influence becomes less significant for higher densities (Pusch, 1980; Sugita et al., 2003; Karnland et al., 2005; Castellanos et al., 2008; Siddiqua et al., 2011). Moreover, studies on the aging effects on the swelling behavior show that the swelling potential may decrease with time due to the rearrangement of clay particles with time (Nalzeny et al., 1967; Day et al., 1994; Subba Rao et al., 2003; Delage et al., 2006).

Very often, bentonite/sand mixtures are considered for the reasons of good control of swelling pressure, large thermal conductivity and a better mechanical resistance. In France, the mixture of bentonite and crushed Callovo-Oxfordian (COx) claystone excavated from the Bure site of the ANDRA URL (-490 m, North-eastern France) was proposed as a possible sealing and backfill material. This choice has several advantages: (i) it is more economical by using local excavated claystone; (ii) the negative impacts on the environment is reduced by recycling the excavated material; (iii) there is better compatibility of mineralogical and chemical compositions with host rock, allowing reduction of complex physico-chemical interaction with the host rock (Andra, 2005; Tang et al., 2011a; Tang et al., 2011b). On the other hand, unlike relatively inert sand, claystone contains clay minerals and interaction between claystone and bentonite may occur, affecting the hydro-mechanical behaviour of the compacted mixture. Moreover, this interaction can be of long term. Particular 
attention should be paid to this aspect.

This study focuses on the swelling properties of the mixture MX80 bentonite/crushed Cox claystone. A series of swelling tests were performed under constant temperature $\left(20 \pm 1^{\circ} \mathrm{C}\right)$. The influences of water chemistry, hydration procedure and duration, pre-existing technical void and loading-wetting paths on the swelling pressure of compacted samples were investigated. Emphasis was put on the relationship between the swelling pressure and the dry density of bentonite.

\section{MATERIALS AND METHODS}

\subsection{Materials}

The commercial MX80 bentonite from Wyoming, USA, was used. Table 1 lists its physical parameters. It appears that the proportion of montmorillonite is dominant in the bentonite ( $92 \%$ ); it has an average specific gravity of 2.76 , a liquid limit of $520 \%$, and a plastic limit of $42 \%$. The grain size distribution determined by sedimentation in Figure 1 shows that $84 \%$ grains are smaller than $2 \mu \mathrm{m}$ (clay fraction).

Callovo-Oxfordian (COx) claystone taken from the Bure site of the ANDRA URL was studied. It contains $40-45 \%$ clay minerals (mainly interstratified minerals illite-smectite), 20-30\% carbonates and 20-30\% quartz and feldspar (Hoteit et al., 2000; Lebon and Ghoreychi, 2000; Zhang et al., 2004). The specific gravity is 2.70 . The excavated claystone was air-dried $(\mathrm{w}=2.64 \%)$ and crushed to powder. The grain size distribution determined by sedimentation is presented in Figure 1. It confirms that $40 \%$ grains are clays $(<2 \mu \mathrm{m})$.

Both distilled water and synthetic water having the same chemical composition as the site water (see Table 2) were used.

\subsection{Samples preparation}

All the tests in this study were performed on samples of compacted bentonite/claystone mixture with a bentonite content of $70 \%$ in dry mass. Bentonite and claystone powders with the initial water contents of $11.8 \%$ and $2.64 \%$ respectively, were used for the samples preparation. Their grain size distributions were determined by sieving and are presented in Figure 1.

Samples were statically compacted in an oedometer cell $(38$ or $70 \mathrm{~mm}$ in internal diameter) at a controlled rate of $0.05 \mathrm{~mm} / \mathrm{min}$. A load transducer was used for axial force monitoring, and a micrometer dial gauge was used for axial displacement monitoring. After compaction, the specimen was carefully transferred into the hydration cell (with the same diameter as the oedometer cell) by connecting the bottom of the two cells together. This procedure allows the lateral stress released without significant increase in sample diameter. 
Various methods were used to determine the swelling pressure upon wetting. The stress paths of these methods are presented in Figure 2.

For the "constant-volume" method (stress path OA), the devices presented in Figure 3 and Figure 4 were used. The constant-volume cell includes three parts (Figure 3, Tang et al., 2011b): (1) the bottom part containing a porous stone and a drainage system; (2) the middle cell (70 $\mathrm{mm}$ inner diameter) used to prevent radial swelling, with two air outlets; (3) the top part incorporating a total pressure sensor to monitor the swelling pressure. Figure 4 presents the setup used to control the suction in the soil sample using the vapour equilibrium technique (see Delage et al., 1998 for more details). When flooding the soil sample, this system was removed and the water inlet was connected to a water reservoir.

For the "pre-swell" method (stress path OBB'), the sample was first allowed to swell freely in the axial direction to a certain value (Point B, noted as "pre-swell"), then the piston was fixed permitting the generation of swelling pressure that was monitored by the load transducer. This method was used to investigate the effect of pre-existing technical voids (simulated by the pre-swell allowed in the tests) on the swelling pressure.

For the "zero-swell" and "swell-consolidation" methods, the equipment employed was a conventional oedometer (Basma et al., 1995; Nagaraj et al., 2009). Firstly, a low initial load of $0.1 \mathrm{MPa}$ was exerted on the specimen prior to water flooding. As the specimen wetted up it attempted to swell. When the swell exceeded $10 \mu \mathrm{m}$ (equivalent to $0.1 \%$ ), additional pressure was added in small increment to bring the volume of soil specimen back to its initial value (Basma et al., 1995; Abdullah et al., 1998, 1999; Attom et al., 2001). This operation was repeated until the specimen ceased to swell (OCC' in Figure 2). The swelling pressure was defined as the stress under which no more swelling strain was observed.

The "swell-consolidation" method consists of re-saturating the soil under a low vertical pressure of 0.1 MPa until full swell was achieved. After swell completion, standard consolidation test was conducted. The pressure required to compress the specimen back to its original void ratio is defined as the swelling pressure (Basma et al., 1995; Abdullah et al., 1998, 1999; Agus, 2005). The corresponding stress path $\mathrm{ODD}^{\prime}$ is shown in Figure 2. In this path, point D also represents the maximum swelling strain of the sample.

The experimental programme is shown in Table 3. Three tests were performed using the constant-volume method to study the effect of water chemistry and the hydration procedure (CV01, CV02 and CV03). Distilled water and synthetic water was used in test CV01 and CV02, respectively. In test CV03, three suctions (57 MPa, $38 \mathrm{MPa}$ 
and 12.6 MPa) were first applied step by step using vapor equilibrium technique (as shown in Figure 4), prior to distilled water flooding in the last stage.

Four tests were performed by pre-swell method to study the influence of pre-existing technical voids on the swelling pressure (PS01 - PS04). Different pre-swells were allowed before measurement of the swelling pressure. Note that for test PS04 the sample was allowed to swell freely to reach the maximum pre-swell strain.

Two other tests were conducted using zero-swell method (ZSO1) and swell-consolidation method (SCO1), respectively, for analyzing the influence of loading-wetting paths followed in different experimental methods.

As it can be seen in Table 3, the tests conducted have in general long duration, from $80 \mathrm{~h}$ to one year.

\section{EXPERIMENTAL RESULTS}

Figure 5 presents the results from tests CV01 and CV02 with distilled water and synthetic water respectively, during the first $100 \mathrm{~h}$. The two curves are very similar, showing negligible effect of water chemistry (in the range considered). With water infiltration, swelling pressure increased first very quickly; after about $20 \mathrm{~h}$ the swelling pressure reached a first stability stage. At $32 \mathrm{~h}$, the swelling pressure restarted to increase and it reached a second stability stage at $100 \mathrm{~h}$. The final values are 4.30 MPa and 4.37 MPa for CV01 and CV02, respectively.

The results of test CV03 is presented in Figure 6. The initial suction of sample was about $90 \mathrm{MPa}$ (measured by a relative humidity sensor on the soil specimen after the compaction and prior to the installation in the cell). The application of the first suction of $57 \mathrm{MPa}$ resulted in a swelling pressure of $0.57 \mathrm{MPa}$. Then, the second suction of $38 \mathrm{MPa}$ was applied and the swelling pressure reached $1.43 \mathrm{MPa}$. With the third suction of 12.6 MPa the swelling pressure increased to 2.61 MPa. The zero suction applied by distilled water led the sample to a maximum value of $4.39 \mathrm{MPa}$ swelling pressure. This value is very close to that from test CV01 (4.30 MPa) and CV02 (4.37 MPa) in which the samples were flooded directly with water. This means there is no kinematic effect on the swelling pressure for the studied mixture.

Figure 7 presents the relationship between the swelling pressure $\left(\sigma_{\mathrm{s}}\right.$ in MPa) and the suction ( $\mathrm{s}$ in $\mathrm{MPa}$ ), with the values obtained from test CV03. An exponential function can be used to satisfactorily describe this relationship:

$$
\sigma_{s}=4.9908 \times 10^{-0.0178 s}
$$

In Figure 8, the whole results from the three tests CV01, CV02 and CV03 during one year are presented. It appears that after a long period of one year, there was just a 
slight decrease of swelling pressure and the values for the three samples still remain very close (4.23MPa, $4.32 \mathrm{MPa}$ and $4.29 \mathrm{MPa}$ for test CV01, CV02 and CV03, respectively). This shows a negligible effect of any bentonite-claystone interaction on the swelling pressure.

The evolution of swelling pressure for the specimens having the same initial dry density of $1.90 \mathrm{Mg} / \mathrm{m}^{3}$ with different pre-swells is presented in Figure 9. An expected significant decrease of swelling pressure with increasing pre-swell is observed. For the pre-swells of 10, 20 and $25 \%$, the swelling pressures obtained are 5.38, 2.03 and $0.7 \mathrm{MPa}$, respectively. Note that the maximum swelling strain from test PS04 reaches $43 \%$.

The results from test SCO1 using the swell-consolidation method are presented in Figure 10. When wetting up, the sample swelled under a low vertical pressure of $0.1 \mathrm{MPa}$ and the maximum swelling strain reached $41.76 \%$. Further compression gave a normal consolidation curve that allows the determination of the swelling pressure: $\sigma_{\mathrm{s}}=22.20 \mathrm{MPa}$.

For test ZSO1 (zero-swell method) on a sample at an initial dry density of $1.70 \mathrm{Mg} / \mathrm{m}^{3}$, a vertical stress of $4.38 \mathrm{MPa}$ was needed to keep the void radio constant. By definition, this value is the swelling pressure by this method.

From the results in Figure 9, the swelling pressure is plotted versus the pre-swell strain in Figure 11. The maximum pre-swell of test PS04 and the swelling strain in SCO1 (swell consolidation method) are also presented in this figure. Note that all specimens had the same initial dry density of $1.90 \mathrm{Mg} / \mathrm{m}^{3}$ and all flooded with synthetic water. It appears that the result of SCO1 is close to that of PS04 (free swell), showing a good repeatability of the free-swell tests. A linear correlation can be obtained between the swelling strain allowed $(\varepsilon$ in $\%$ ) and the logarithm of swelling pressure $\left(\sigma_{\mathrm{s}}\right.$ in $\left.\mathrm{MPa}\right)$ :

$$
\varepsilon=-19.32 \operatorname{Lg}\left(\sigma_{s}\right)+23.946
$$

In Figure 12, the swelling pressure determined by the pre-swell method (PS01, PS02, PS03, PS04), constant-volume method (CV02), zero swell method (ZSO1) are plotted in the plane of void ratio/logarithm of vertical stress, together with the consolidation line from test SCO1. Point $\mathrm{O}$ and $\mathrm{O}^{\prime}$ correspond to the initial states of the samples at a dry density of $1.90 \mathrm{Mg} / \mathrm{m}^{3}$ (PS01, PS02, PS03, PS04 and SCO1) and $1.70 \mathrm{Mg} / \mathrm{m}^{3}$ (CV02 and ZSO1), respectively. It can be noted that at the same void ratio, the vertical stress of the consolidation curve (SCO1) is slightly higher than the swelling pressure determined by other methods.

Figure 13 shows the measured swelling pressure versus the final dry density of the bentonite/claystone mixture for all the tests. Note that these tests have been performed with two different initial dry densities $\left(\rho_{d i}=1.90 \mathrm{Mg} / \mathrm{m}^{3}\right.$ for tests PS01, 
PS02, PS03, PS04, SCO1; and $\rho_{d i}=1.70 \mathrm{Mg} / \mathrm{m}^{3}$ for tests CV02, ZSO1), and using various methods (see Table 3). In spite of this, a unique correlation seems enough to describe the relationship between the swelling pressure $\sigma_{s}(\mathrm{MPa})$ and the final dry density of the mixture $\rho_{d m}\left(\mathrm{Mg} / \mathrm{m}^{3}\right)$ :

$$
\sigma_{s}=4.8 \times 10^{-7} \exp ^{9.41 \rho_{d m}}
$$

This shows that the swelling pressure of the compacted claystone/bentonite mixture is mainly dependent on the final dry density of the mixture. For a deeper analysis on the role of the bentonite itself in the swelling pressure development of the bentonitebased mixutre, the dry density of bentonite $\left(\rho_{d b}\right)$ was considered by assuming that the water content of additives (claystone in this study) kept constant, while the water added during the tests was totally absorbed by bentonite. The volume of bentonite $\left(\mathrm{V}_{b}\right)$ is the difference between the total volume $(\mathrm{V})$ and the volume of claystone (soil particles and water inside). The bentonite dry density can be calculated by the following equation:

$$
\rho_{d b}=\frac{(B / 100) \rho_{m} G_{s a}}{G_{s a}\left(1+w_{m} / 100\right)-\rho_{m}(1-B / 100)\left(1+w_{a}\right)}
$$

where $\rho_{m}\left(\mathrm{Mg} / \mathrm{m}^{3}\right)$ is the mixture density; $B(\%)$ is the bentonite content (in dry mass) in the mixture; $w_{m}$ is the water content of the mixture; $w_{a}$ is the initial water content of claystone; $G_{s a}$ is the specific gravity of claystone. In this study, $w_{a}=2.64 \%, B=$ $70 \%, G_{s a}=2.70$.

Using Eq. 4, the results shown in Figure 13 were re-analysed and Figure 15 shows the variations of swelling pressure with the final dry density of bentonite. In the same figure, the results collected from other works on the MX80/sand mixture (Karland et al., 2008) and the pure MX80 bentonite (Karnland et al., 2008; Dixon et al., 1996) are also presented. A very similar relationship is obtained for the different data sets, showing that the swelling pressure mainly depends on the final dry density of bentonite, sand and claystone being both inactive components in the mixtures for the swelling pressure development.

To further investigate this point, results on other reference bentonites were collected and analysed in the same fashion. Figure 15 shows the variations of swelling pressure with the final dry density of MX80 (from Figure 14), FoCa7 (Imbert et al., 2006), FEBEX (Villar et al., 2002) and Kunigel V1 (Dixon et al., 1996). It appears that for each bentonite, there is a unique relationship between the swelling pressure and the final dry density of bentonite. However, the relationships are not the same. A general expression can be proposed:

$$
\sigma_{s}=\alpha \times \exp ^{\beta \rho_{d b}}
$$

where $\alpha$ and $\beta$ are the two constants. 
Table 4 shows the values of $\alpha$ and $\beta$ for the four bentonites analysed. In the table, the mineralogy of these materials is also presented. The difference of parameters can be related to the different types of clay (i.e. montmorillonite, beidellite and saponite, etc), montmorillonite content and type of exchangeable cations (i.e. calcium or sodium). In general, the swelling capacity of sodium bentonite is higher than that of calcium bentonite; with the same type of exchangeable cations, a larger montmorillonite content leads to a higher swelling pressure.

\section{DISCUSSION}

It has been observed that the effect of the chemistry of Bure site water on the swelling pressure is negligible. However, it is generally accepted that the swelling pressure decreases with the increase in salinity of the pore-water, although this decrease becomes less significant in case of high density (Karnland et al., 2005; Castellanos et al., 2008; Siddiqua et al., 2011; Komine et al., 2009). Castellanos et al. (2008) reported that the swelling pressure of the FEBEX bentonite compacted to a dry density of $1.65 \mathrm{~g} / \mathrm{cm}^{3}$ decreases to almost half its initial value when $2 \mathrm{~mol} / \mathrm{L} \mathrm{CaCl}_{2}$ and $\mathrm{NaCl} / \mathrm{L}$ solutions are used as saturating fluids; At low salinities $(0.004 \mathrm{~mol} / \mathrm{L}$, granitic water), the swelling pressure of bentonite seems not to be affected by the salinity changes at a dry density ranging from 1.40 to $1.70 \mathrm{Mg} / \mathrm{m}^{3}$. It appears that for the studied bentonite/claystone mixture, the high density and the low salinity of synthetic water together resulted in the negligible effect of water chemistry on the swelling pressure. This can be explained by the theory of cations filtration (Komine et al., 2009). For high dry density of bentonite-based materials, the distances between the montmorillonite mineral layers being very small, these layers can filter the cations in the solution; on the contrary, in the case of low dry density, the cations in solution can infiltrate easily into the montmorillonite mineral layers due to the larger distances between them, thus affecting the swelling behaviour.

For the sample wetted with suction control (CV03), an exponential function was found between the swelling pressure and the suction applied. This can be explained as follows. As clay samples are exposed to humid water vapour, water molecules first migrate into the open channels and adsorbed on the exposed mineral surface (Pusch, 2001b; Arifin, 2008), then move to elementary clay layers. The number of water molecules absorbed by the clay layers depends on the relative humidity or suction (Pusch, 2001b; Saiyouri et al., 2004; Delage, 2006), and this number of water molecules defines the swelling pressure of the sample. Therefore the swelling pressure is suction or relative humidity dependent. After the sample was flooded with distilled water, the maximum swelling pressure was found close to that obtained by water-flooding the sample directly, indicating the negligible effect of wetting procedure. This phenomenon can be explained by the mechanism identified by Cui et al. (2002): when hydrating by decreasing suction (57-38-12.6 MPa) under confined conditions, the size of macro-pores was progressively decreased, whereas the micro-pores remained almost un-affected. The micro-pores started to change 
only when the water saturation is approached. This suggests that step-wetting by suction control and direct saturation by water flooding may lead to similar final microstructures, thus similar final swelling pressures.

Yang et al. (2008) reported that the mineralogical composition of the bentonite will not be stable under the chemistry fluid infiltration and its properties may degrade over long time periods. Moreover, for the bentonite/claystone mixture used in this study, interaction of claystone with water and bentonite was suspected. This justifies the long swelling tests kept over one year. However, no any significant effects were observed on the swelling pressure. It is possible that one year test is not long enough and this point should be studied further with longer tests, giving the long-term nature of the nuclear waste disposal.

A linear correlation was observed between the pre-swelling strain and the logarithm of swelling pressure for the samples with the same initial dry density. This line defines the limit of swelling potential: the samples at the same initial state followed different stress-volume paths until reached this limit and then no further expansion occurred. This is consistent with the conclusion of Villar et al. (2008) and Siemens et al. (2009) who found a similar relationship between swelling strain and swelling pressure. It can be seen that the final state of specimen governed the swelling pressure: for the samples with the same initial state, different pre-swelling strains led to different final dry densities and thus resulted in different swelling pressure. Moreover, a unique relationship was observed between the swelling pressure and the final dry density of the samples whatever the initial dry density, the percentage of pre-swell and the experimental method. This also enhances the conclusion that the final state of the sample controls the swelling pressure. Further analysis showed that the swelling pressure mainly depends on the final dry density of bentonite in the mixture. This observation is in agreement with the conclusion of Lee et al. (1999) and Agus (2005) who noted that the swelling pressure of bentonite/sand mixtures with different bentonite contents is a function of the final bentonite dry density. This suggests that the swelling mechanism of bentonite-based materials is the same as that of pure bentonites.

At the same void ratio, the swelling pressure determined by different methods was found slightly lower than the vertical stress needed to reach the same void ratio following the swell-reload path (swell-consolidation method). This was in agreement with the results by many other authors (Justo et al., 1984; Sridharan et al., 1986; Basma et al., 1995; Abdullah et al., 1998, 1999; Agus, 2005; Villar, 1999; Villar et al., 2008), and can be considered as a consequence of the coupling between the microstructure and macrostructure (Gens and Alonso, 1992; Villar, 1999; Sánchez et al., 2005). For the swell-consolidation oedometer test, wetting took place under a low vertical load and the void ratio increased greatly due to the large microstructural changes. In this case, intense breakage of particle aggregates occurs, leading to relatively uniform distribution of the expandable component. A relatively high vertical stress was needed to compensate this large macrostructure deformation. By 
contrast, smaller microstructure and macrostructure interaction is expected in other methods, with lower stress at full saturation. Furthermore, the relative larger displacement in the swell-consolidation oedometer test would mobilise higher friction and this friction can also contribute to the phenomenon observed.

\section{CONCLUSION}

The swelling pressure of bentonite/claystone mixture was determined by different methods. The effects of the water chemistry, the hydration procedure, the pre-existing technical voids and the experimental methods on the swelling pressure were investigated. From the experimental results the following conclusion can be drawn.

There was no obvious effect of water chemistry on the swelling pressure due to the high density and the low salinity of synthetic water.

An exponential function was found between the swelling pressure and the suction applied; no effect of hydration procedure on the final swelling pressure was observed.

The swell-consolidation method gives higher swelling pressure mainly because of the coupling between the microstructure deformation and macrostructure deformation. The effect of friction is also to be considered for this phenomenon.

The swelling pressure of bentonite-based materials mainly depends on the final dry density of the bentonite in the mixture, suggesting that the swelling mechanism of bentonite-based materials is the same as that of pure bentonites. A general relationship between the swelling pressure and the final dry density of various bentonites was proposed, with two parameters depending on the montmorillonite content and the type of exchangeable cations.

From a practical point of view, the relationship elaborated between the swelling pressure and the final bentonite dry density is helpful in designing the sealing/filling buffers with bentonite-based materials: when the initial state of bentonite-based materials and the technical voids are known, the final swelling pressure can be predicted. Moreover, the crushed Cox claystone can be used to form the bentonite/claystone mixture because it behaves as sand. However it should be noted that this conclusion is based on the results from one year tests and further studies with longer tests are needed to gain more confidence on this aspect.

\section{Acknowledgements}

This work was conducted within the framework of GM2 of the French National Agency for Nuclear Waste Management (ANDRA). The conclusions and the viewpoints presented in the paper are those of the authors and do not necessarily coincide with those of ANDRA. The support from the PHC Cai Yuanpei project (24077QE) and that of the China Scholarship Council (CSC) are also greatly acknowledged. 


\section{REFERENCE}

420

421

422

423

424

425

426

427

428

429

430

431

432

433

434

435

436

437

438

439

440

441

442

443

444

445

446

447

448

449

450

451

452

453

454

455

456

457

458

459

460

Abdullah, I., Mhaidib, A., 1998. Prediction of swelling potential of an expansive shale. Proceedings Of The Second International Conference On unsaturated soils. 27-30 August. Beijing, China: vol. 1.

Abdullah, I., Mhaidib, A.l., 1999. Swelling behaviour of expansive shales from the middle region of Saudi Arabia. Geotechnical and Geological Engineering. 16(4):291-307.

Agus, S., 2005. An Experimental study on hydro-mechanical characteristics of compacted bentonite-sand mixtures. $\mathrm{PhD}$ thesis. Weimar.

Agus, S., Schanz, T., 2005. Swelling pressures and wetting-drying curves of a highly compacted bentonite-sand mixture. Unsaturated Soils: Experimental Studies, pages 241-256.

Andra, 2005. Référentiel des matériaux d'un stockage de déchets à haute activité et à vie longue - Tome 4: Les matériaux à base d'argilites excavées et remaniées. Rapport Andra $\mathrm{N}^{\circ}$ CRPASCM040015B.

Arifin, Y.F., 2008. Thermo-hydro-mechanical behavior of compacted bentonite sand mixtures: An Experimental Study. PhD thesis. Weimar.

Attom, M.; Abu-Zreig, M. \& Obaidat, M. 2001. Changes in clay swelling and shear strength properties with different sample preparation techniques. ASTM geotechnical testing journal, ASTM, 24, 157-163.

Barnichon, J.D., and Deleruyelle, F., 2009. Sealing Experiments at the Tournemire URL. Towards convergence of technical nuclear safety practices in Europe, EUROSAFE.

Basma,A.A., Al-Homoud, A.S., Husein, A., 1995. Laboratory assessment of swelling pressure of expansive soils. Applied Clay Science, 9(5):355-368.

Borgesson, L. 1985. Water flow and swelling pressure in non-saturated bentonite-based clay barriers. Engineering Geology, 21(3-4):229-237.

Borgesson, L., Chijimatsu, M., Fujita,T., Nguyen, T.S., Rutqvist, J., Jing, L., 2001. Thermo-hydro-mechanical characterisation of a bentonite-based buffer material by laboratory tests and numerical back analyses. International Journal of Rock Mechanics and Mining Sciences, 38(1):95-104.

Castellanos, E., Villar, M.V., Romero, E., Lloret, A., Gens, A., 2008. Chemical impact on the hydro-mechanical behaviour of high-density febex bentonite. Physics and Chemistry of the Earth, Parts A/B/C, 33(Supplement 1):S516 - S526.

Cui, Y. J., Loiseau, C., Delage, P., 2002. Microstructure changes of a confined swelling soil due to suction controlled hydration Unsaturated soils: proceedings of the Third International Conference on Unsaturated Soils, UNSAT 2002, 10-13 March 2002, Recife, Brazil, 593.

Cui, Y.J., Tang, A.M., Loiseau, C., Delage, P., 2008. Determining the unsaturated hydraulic conductivity of a compacted sand-bentonite mixture under constant-volume and free-swell conditions. Physics and Chemistry of the Earth, Parts A/B/C, 33(Supplement 1): 462 - S471.

Day, R.W. 1994. Swell-shrink behaviour of expansive compacted clay. J. Geotechnical 
Engneering, ASCE 120, No. 3, 618-623.

Delage, P., Howat, M. D. \& Cui, Y. J., 1998. The relationship between suction and swelling properties in a heavily compacted unsaturated clay. Engineering Geology 50, 31-48.

Delage, P., Marcial, D., Cui, Y.J., and Ruiz, X., 2006. Ageing effects in a compacted bentonite: a microstructure approach. Geotechnique, 56(5):291-304.

Delage, P. 2006. Some microstructure effects on the behaviour of compacted swelling clays used for engineered barriers. Chinese Journal of Rock Mechanics and Engineering, Science Press(Beijing), 16 Donghuangchenggen North St, Beijing, 100717, China,, 25, 721-732.

Delage, P., Cui, Y.J., Tang, A.M., 2010. Clays in radioactive waste disposal, Journal of Rock Mechanics and Geotechnical Engineering, Vol (2):111-123.

Dixon, D.A., Gray, M.N., Graham, J., 1996. Swelling and hydraulic properties of bentonites from Japan, Canada and USA. In Proceedings of the second International Congress on Environmental Geotechnics, Osaka, Japan, pages 5-8.

Dixon, D.A., Graham, J., and Gray, M.N., 1999. Hydraulic conductivity of clays in confined tests under low hydraulic gradients. Canadian Geotechnical Journal, 36(5):815-825.

Gens, A., Alonso, E.E. 1992. A framework for the behaviour of unsaturated expansive clays. Canadian Geotechnical Journal, 29(6):1013-1032.

Hoteit N, Ozanam-O, Su, K. 2000. Geological radioactive waste disposal project in franceconceptual model of a deep geological formation and underground research laboratory in Meuse Haute-Marne site. In The 4th North American Rock Mechanics Symposium, Seattle, July 31-August 3.

Imbert, C., and Villar, M.V., 2006. Hydro-mechanical response of a bentonite pellets-powder mixture upon infiltration. Applied Clay Science, 32(3-4):197-209.

Justo, J.L., Delgado, A., Ruiz, J., 1984. The influence of stress-path in the collapse-swelling of soils at the laboratory. In Fifth International Conference on Expansive Soils 1984. Australia. Page 67.

Karnland, O., Muurinen, A., Karlsson, F., 2005. Bentonite swelling pressure in $\mathrm{NaCl}$ solutions-Experimentally determined data and model calculations. Advances in Understanding Engineering Clay Barriers. Page 241.

Karnland, O., Nilsson, U., Weber, H., and Wersin, P., 2008. Sealing ability of Wyoming bentonite pellets foreseen as buffer material-Laboratory results. Physics and Chemistry of the Earth, Parts A/B/C, 33:S472-S475.

Kenney, T.C., Veen, W.A.V., MA Swallow, and Sungaila., M.A., 1992. Hydraulic conductivity of compacted bentonite-sand mixtures. Canadian Geotechnical Journal, 29(3):364-374.

Komine., H., Ogata, N. 1994. Experimental study on swelling characteristics of compacted bentonite. Canadian geotechnical journal, 31(4):478-490.

Komine., H., Ogata, N. 1998. Thermal influence on compacted bentonite for nuclear waste disposal. In Proceedings of the 3rd International Congress on Environmental Geotechnics, volume 1, pages 34-39.

Komine., H., Ogata, N. 2003. New equations for swelling characteristics of bentonite-based buffer materials. Canadian Geotechnical Journal, 40(2):460-475.

Komine., H., Ogata, N. 2004a. Predicting swelling characteristics of bentonites. Journal of 
Geotechnical and Geoenvironmental engineering, 130:818.

Komine, H., 2004b. Simplified evaluation for swelling characteristics of bentonites, Engineering geology, 71(3-4): 265-279.

Komine, H. Yasuhara, K. and Murakami, S. 2009. Swelling characteristics of bentonites in artificial seawater. Canadian Geotechnical Journal, 46(2):177-189.

Kröhn, K.P. 2003. Results and interpretation of bentonite resaturation experiments with liquid water and water vapour. In: Schanz, T. (Ed.), Proceedings of the International Conference from Experimental Evidence towards Numerical Modeling of Unsaturated Soils, Weimar, Germany, vol. 1. 598 Springer, Berlin, pp. 257-272.

Lebon, P. and Ghoreychi, M. 2000. French underground research laboratory of Meuse, Haute-Marne THM aspects of argillite formation. In Eurock 2000 Symposium, March, pages $27-31$.

Lee, J.O., Cho, W.J. and Chun, K.S., 1999. Swelling Pressures of a Potential Buffer Material for High-Level Waste Repository. Journal of the Korean Nuclear Society, 31: 139-150.

Lemaire, T., Moyne, C., and Stemmelen, D., 2004. Imbibition test in a clay powder (MX-80 bentonite). Applied Clay Science, 26(1-4):235-248.

Li, X.L., Bastiaens, W., Van Marcke, P., et al., 2009. Design and Development of the Large Scale In-situ PRACLAY Heater Test and Horizontal HLW Disposal Gallery Seal Test in Belgian URL Hades,International Symposium on Unsaturated Soil Mechanics and Deep Geological Nuclear Waste Disposal, Shanghai, China: 24-28.

Loiseau, C., Cui, Y.J. and Delage, P., 2002. The gradient effect on the water flow through a compacted swelling soil, In: Proc. 3rd Int Conf Unsaturated Soils, UNSAT 2002, Recife, Brazil, Balkema 1:395-400.

Nagaraj, H.; MOHAMMED Munnas, M.; Sridharan,A., 2009. Critical Evaluation of Determining Swelling Pressure by Swell-Load Method and Constant Volume Method, ASTM geotechnical testing journal, ASTM, 32, 305-314.

Nalezny, C. L. \& Li, M. C., 1967. Effects of soil moisture and thixotropic hardening on the swell behaviour of compacted expansive soils. Highway Res. Rec. Washington, DC: Highway Research Board. No. 209.

Pusch, R., 1979. Highly compacted sodium bentonite for isolating rock-deposited radioactive waste products. Nucl. Technol, United States. 45(2):153-157.

Pusch, R. 1980. Swelling pressure of highly compacted bentonite. SKBF/KBS technical report: No.80-13.

Pusch, R., 1982. Mineral-water interactions and their influence on the physical behavior of highly compacted Na bentonite. Canadian Geotechnical Journal, 19(3):381-387.

Pusch, R., 2001a. Experimental study of the effect of high porewater salinity on the physical properties of a natural smectitic clay, SKBF/KBS technical report. No.TR01-07.

Pusch, R. 2001b. The microstructure of MX-80 clay with respect to its bulk physical properties under different environmental conditions, SKBF/KBS technical report. No.TR01-08.

Romero, E., Gens, A., and Lloret, A., 2001. Temperature effects on the hydraulic behaviour of an unsaturated clay. Geotechnical and Geological Engineering, 19(3):311-332.

Saiyouri, N., Tessier, D., and Hicher, P.Y., 2004. Experimental study of swelling in 
unsaturated compacted clays. Clay Minerals, 39(4):469.

Sanchez, M., Gens, A., Do Nascimento Guimarães, L., Olivella, S., 2005. A double structure generalized plasticity model for expansive materials. International Journal for Numerical and Analytical Methods in Geomechanics, 29(8):751-787.

Siddiqua, S.; Blatz, J. \& Siemens, G.. 2011. Evaluation of the impact of pore fluid chemistry on the hydromechanical behaviour of clay-based sealing materials. Canadian Geotechnical Journal, NRC Research Press, 48, 199-213.

Siemens, G., and Blatz, J.A., 2009. Evaluation of the influence of boundary confinement on the behaviour of unsaturated swelling clay soils. Canadian Geotechnical Journal, 46(3):339-356.

Sridharan, A., Rao, S., Sivapullaiah, P.V., 1986. Swelling pressure of clays. ASTM geotechnical testing journal, 9(1):24-33.

Sugita, Y., Chijimatsu, M., and Suzuki, H., 2005. Fundamental properties of bentonite pellet for Prototype Repository Project. Advances in Understanding Engineering Clay Barriers, page 293.

Suzuki, S.; Prayongphan, S.; Ichikawa, Y. \& Chae, B. 2005. In situ observations of the swelling of bentonite aggregates in $\mathrm{NaCl}$ solution, Applied Clay Science, Elsevier, 29: 89-98.

Subba Rao, K. S. \& Tripathy, S. 2003. Effect of aging on swelling and swell-shrink behaviour of a compacted expansive soil. ASTM Geotech. Test. J. 26, No. 1, 36-46.

Tang, A.M., Cui, Y.J., 2005. Controlling suction by the vapour equilibrium technique at different temperatures and its application in determining the water retention properties of MX80 clay. Canadian Geotechnical Journal, 42 (1): 287-296.

Tang, A.M., Cui, Y.J., Barnel, N., 2007. A new isotropic cell for studying the thermo-mechanical behavior of unsaturated expansive soil. Geotechnical Testing Journal, 30 (5): $341-348$.

Tang, A.M., Cui, Y.J., Barnel, N., 2008a. Thermo-mechanical behaviour of a compacted swelling clay. Géotechnique, 58 (1): 45-54.

Tang, A.M., Cui, Y.J., Le, T.T., 2008b. A study on the thermal conductivity of compacted bentonites. Applied Clay Science, 41 (3-4): 181 - 189.

Tang, A.M., Cui, Y.J., 2009. Modelling the thermo-mechanical behaviour of compacted expansive clays. Géotechnique, 59 (3): 185-195.

Tang, C.S., Tang, A.M., Cui, Y.J., Delage, P., Barnichon, J.D., Shi, B., 2011a. A study of the hydro-mechanical behaviour of compacted crushed argillite. Engineering Geology. 118 (3-4):93-103.

Tang, C.S., Tang,A.M., Cui, Y.J., Delage, P., Schroeder, C., De Laure, E., 2011 b. Investigating the Swelling Pressure of Compacted Crushed-Callovo-Oxfordian Argillite. Physics and Chemistry of the Earth. (accepted)

Villar, M.V., Lloret, A., 2004. Influence of temperature on the hydro-mechanical behaviour of a compacted bentonite. Applied Clay Science, 26(1-4):337 - 350.

Villar, M.V., 1999. Investigation of the behaviour of bentonite by means of suction-controlled oedometer tests. Engineering Geology, 54(1-2):67-73.

Villar, M.V., 2002. Thermo-hydro-mechanical characterisation of a bentonite from Cabo de Gata. A study applied to the use of bentonite as sealing material in high level 
600

601

radioactive waste repositories. Publicación Técnica ENRESA 01/2002, Madrid, 258 pp. Villar, M.V., Lloret, A., 2008. Influence of dry density and water content on the swelling of a compacted bentonite. Applied Clay Science, 39(1-2):38-49.

Yang, J., Samper, C., and Montenegro, L., 2008. A coupled non-isothermal reactive transport model for long-term geochemical evolution of a HLW repository in clay. Environmental Geology, 53(8):1627-1638.

Yong, R.N., Boonsinsuk, P., and Wong, G., 1986.Formulation of backfill material for a nuclear fuel waste disposal vault. Canadian Geotechnical Journal, 23(2):216-228.

Zhang, C., and Rothfuchs, T., 2004. Experimental study of the hydro-mechanical behaviour of the Callovo-Oxfordian argillite. Applied Clay Science, 26(1-4):325-336. 
603 Table 1 Characteristics of MX80 bentonite (Tang et al., 2008)

604 Table 2 Chemical components of the synthetic water

605 Table 3 Test programme

606 Table 4 Montmorillonite content and external cations type of several bentonites

\section{$607 \quad$ List of Figures}

608 Figure 1. Grain size distribution of MX80 bentonite and crushed COx claystone

609 Figure 2. Stress path of various experimental methods used to determine the swelling pressure

610 Figure 3. Constant-volume cell

611 Figure 4. Schematic view of constant volume cell with suction control system

612 Figure 5. Evolution of swelling pressure for test CV01 and CV02 during the first $100 \mathrm{~h}$.

613 Figure 6. Evolution of swelling pressure for test CV03 during decreasing of suction.

614 Figure 7. Swelling pressure versus suction of test CV03

615 Figure 8. Evolution of swelling pressure for tests CV01, CV02, and CV03 for 1 year

616 Figure 9. Evolution of swelling pressure with various pre-swells

617 Figure 10. Swelling strain versus vertical stress applied for test SCO1

618 Figure 11. Pre-swell versus swelling pressure

619 Figure 12. Swelling pressure or vertical pressure versus void ratio of mixture

620 Figure 13 . Swelling pressure versus finial dry density of bentonite/claystone mixture

621 Figure 14. Results of various mixtures using MX80 bentonite - swelling pressure versus final dry

622 density of bentonite

623 Figure 15 . Swelling pressure versus final dry density of bentonite 
Table 1 Characteristics of MX80 bentonite (Tang et al., 2008b)

\begin{tabular}{ll}
\hline Montmorillonite (\%) & 92 \\
Quartz (\%) & 3 \\
$\mathrm{w}_{l}(\%)$ & 520 \\
$\mathrm{w}_{p}(\%)$ & 42 \\
$\mathrm{I}_{p}$ & 478 \\
$\rho_{\mathrm{s}}\left(\mathrm{Mg} / \mathrm{m}^{3}\right)$ & 2.76 \\
\hline
\end{tabular}

Table 2 Chemical components of the synthetic water

\begin{tabular}{llllllll}
\hline Components & $\mathrm{NaHCO}_{3}$ & $\mathrm{Na}_{2} \mathrm{SO}_{4}$ & $\mathrm{NaCl}$ & $\mathrm{KCl}$ & $\mathrm{CaCl}_{2} \cdot 2 \mathrm{H}_{2} \mathrm{O}$ & $\mathrm{MgCl}_{2} \cdot 6 \mathrm{H}_{2} \mathrm{O}$ & $\mathrm{SrCl}_{2} \cdot 6 \mathrm{H}_{2} \mathrm{O}$ \\
$\begin{array}{l}\text { Mass (g) } \\
\text { per 1L solution }\end{array}$ & 0.28 & 2.216 & 0.615 & 0.075 & 1.082 & 1.356 & 0.053 \\
\hline
\end{tabular}

Table 3 Test programme

\begin{tabular}{lllll}
\hline Test No. & Injected water & Method & $\begin{array}{l}\text { Initial dry density } \\
\left(\mathbf{M g} / \mathbf{m}^{\mathbf{3}}\right)\end{array}$ & Duration \\
\hline CV01 & Distilled & Constant-volume & 1.70 & 1 year \\
CV02 & Synthetic & Constant-volume & 1.70 & 1 year \\
CV03 & Vapour and distilled & Constant-volume & 1.70 & 1 year \\
PS01 & Synthetic & Pre-swell $\varepsilon=10 \%$ & 1.90 & $100 \mathrm{~h}$ \\
PS02 & Synthetic & Pre-swell $\varepsilon=20 \%$ & 1.90 & $100 \mathrm{~h}$ \\
PS03 & Synthetic & Pre-swell $\varepsilon=25 \%$ & 1.90 & $100 \mathrm{~h}$ \\
PS04 & Synthetic & Pre- swell $\varepsilon=$ max & 1.90 & $80 \mathrm{~h}$ \\
ZSO1 & Synthetic & Zero-swell & 1.70 & $80 \mathrm{~h}$ \\
SCO1 & Synthetic & Swell-consolidation & 1.90 & 4 months \\
\hline
\end{tabular}

Table 4 Montmorillonite content and external cations type of several bentonites

\begin{tabular}{lllll}
\hline Bentonite & $\alpha$ & $\beta$ & $\begin{array}{l}\text { Montmorillonite } \\
\text { Content }(\%)\end{array}$ & Type \\
\hline MX 80 & $1.78 \times 10^{-4}$ & 6.75 & $75-90$ & $\mathrm{Na}$ \\
FEBEX & $9.80 \times 10^{-5}$ & 6.85 & 92 & $\mathrm{Ca}$ \\
& $7.83 \times 10^{-7}$ & 9.24 & 50 Beidellite & $\mathrm{Ca}$ \\
FoCa & & & 50 Kaollite & $\mathrm{Na}$ \\
Kunigel V1 & $3.67 \times 10^{-3}$ & 3.32 & 48 & 48 \\
\hline
\end{tabular}




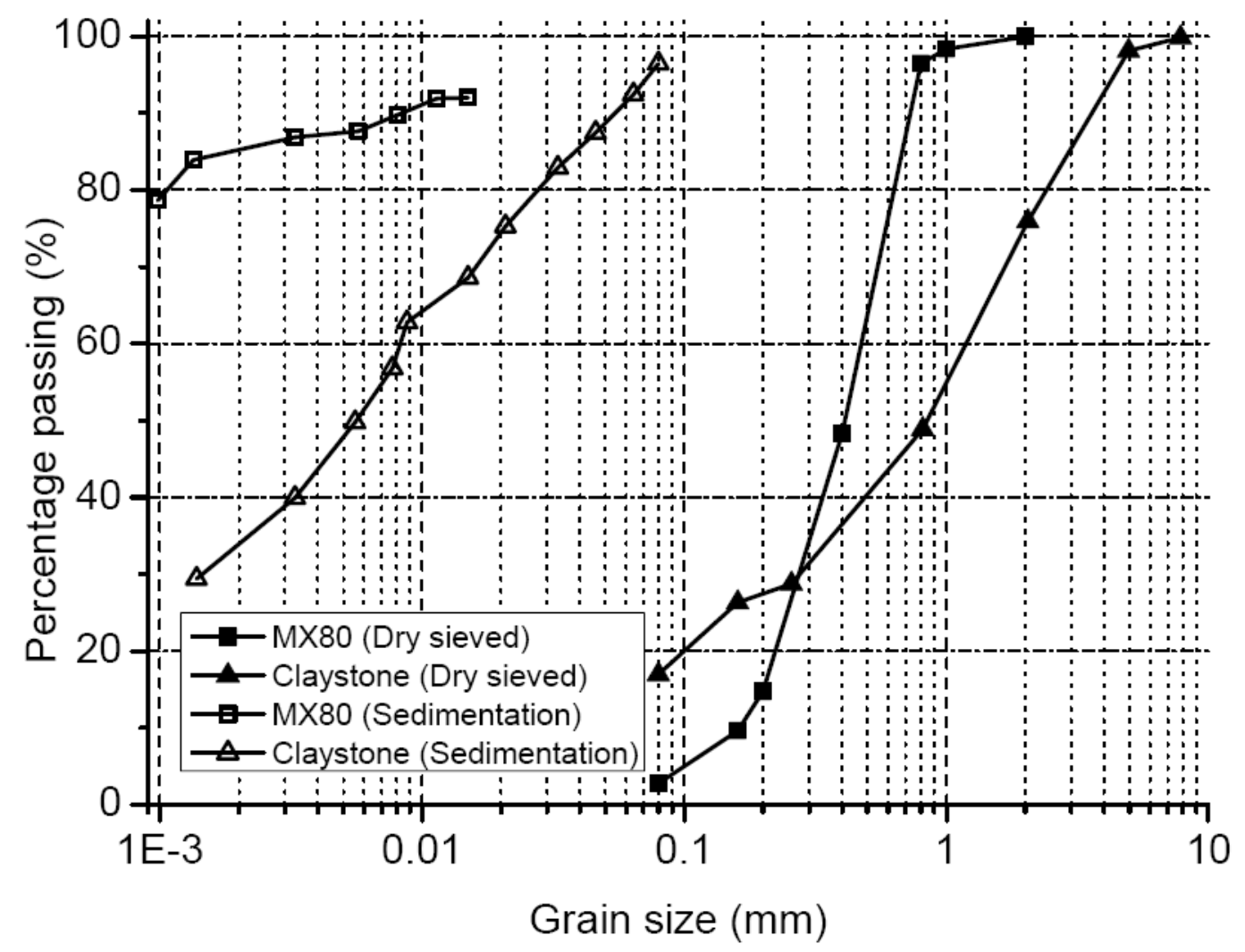

Figure 1. Grain size distribution of MX80 bentonite and crushed COx claystone 


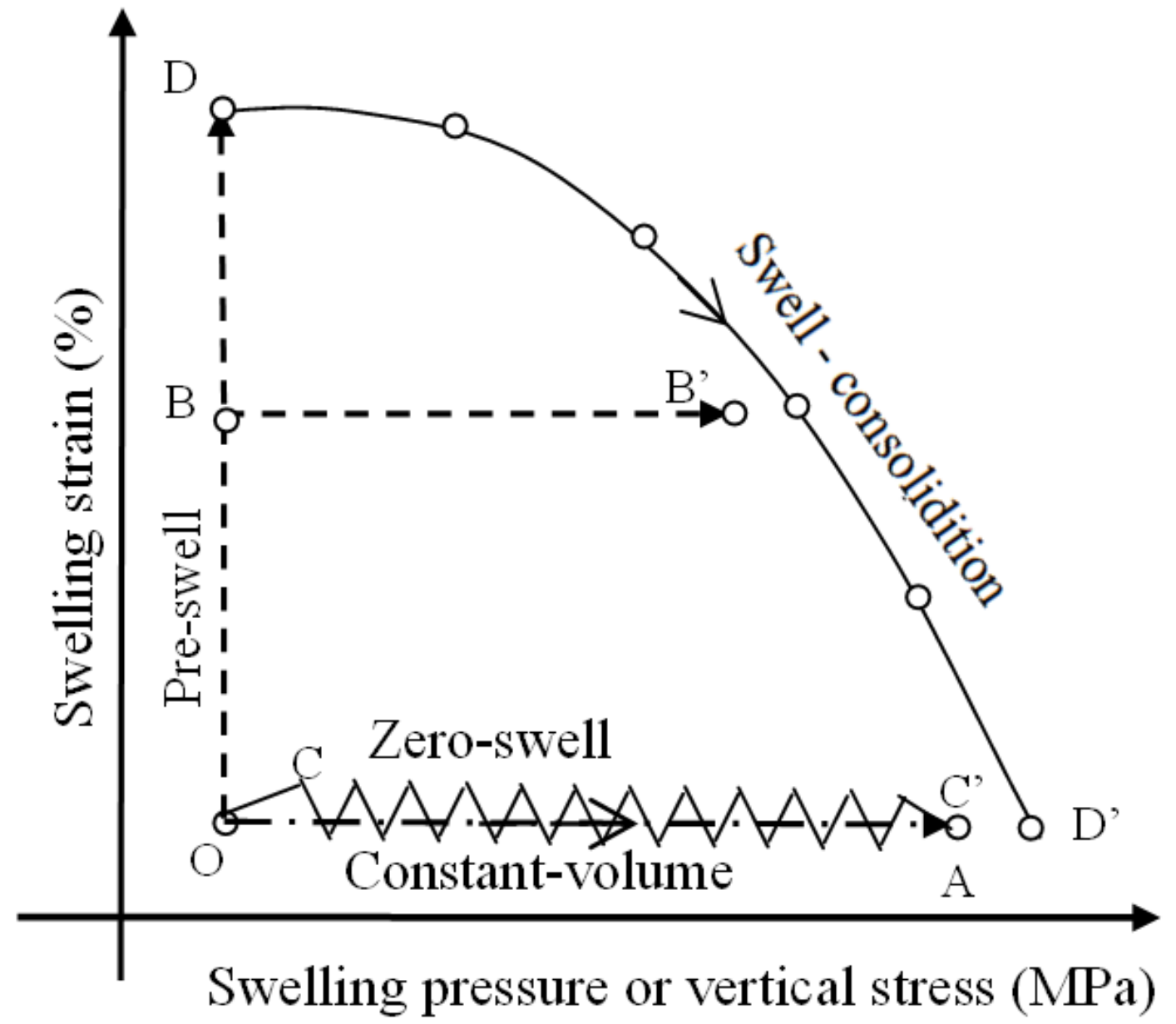

Figure 2. Stress path of various experimental methods used to determine the swelling pressure

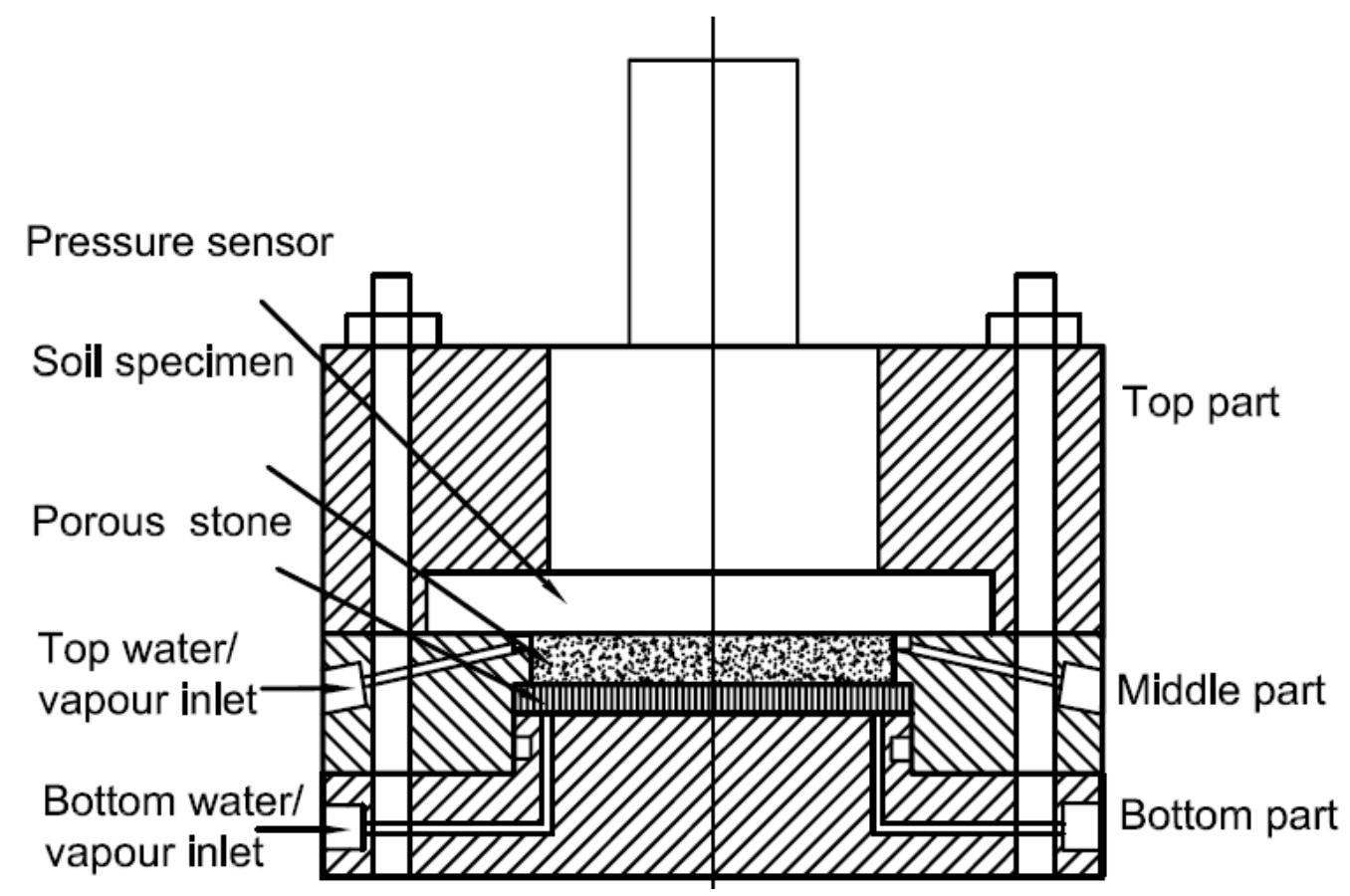

Figure 3. Constant-volume cell 


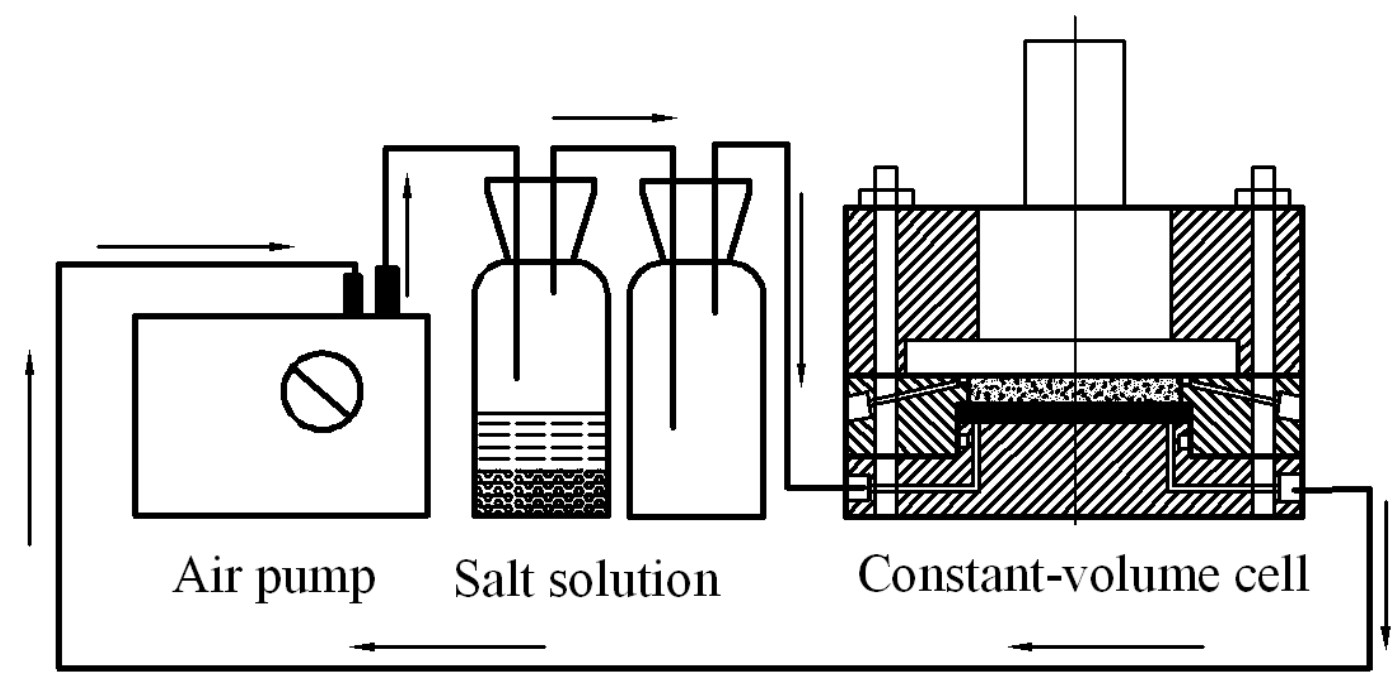

Figure 4. Schematic view of constant volume cell with suction control system

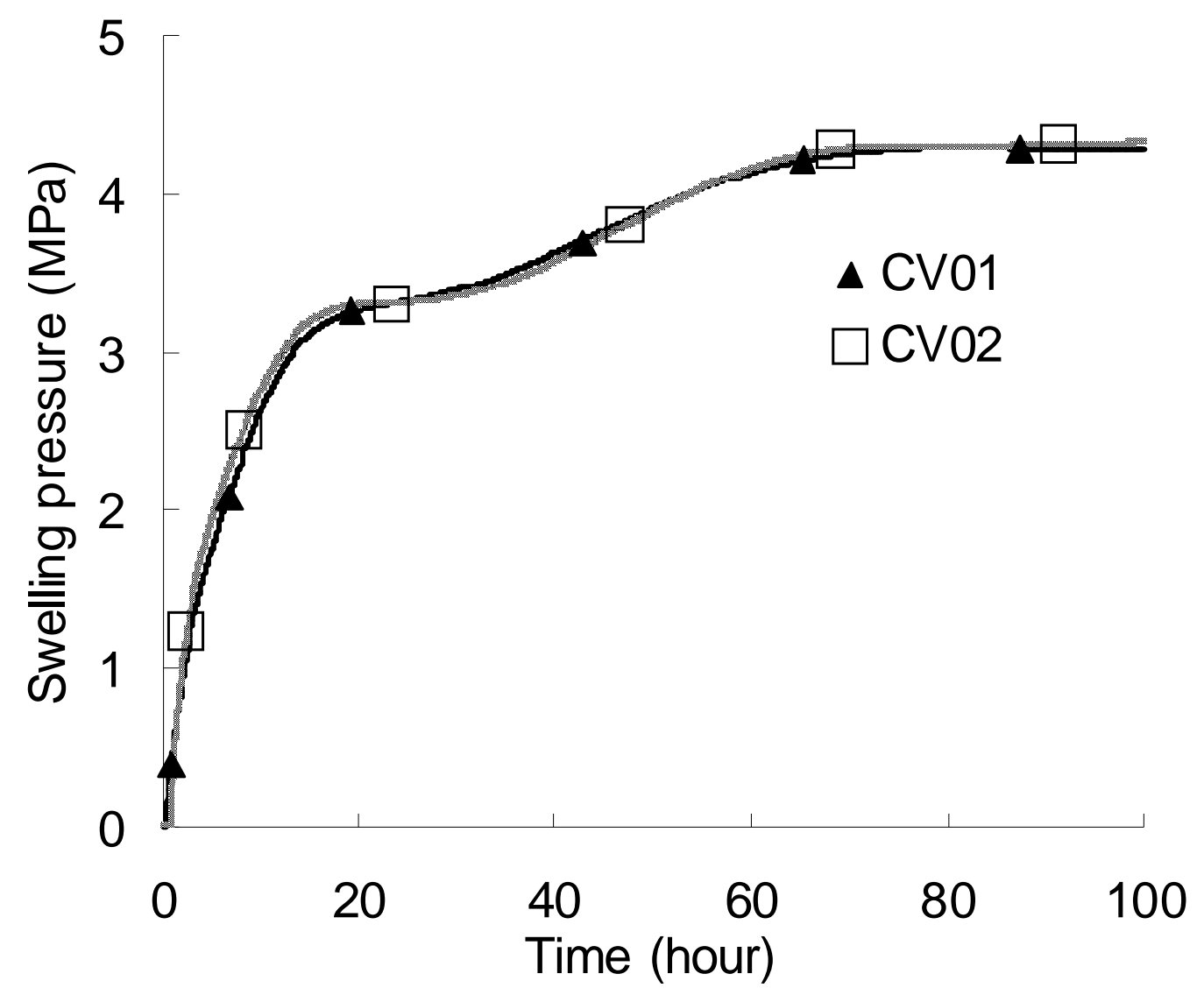

Figure 5. Evolution of swelling pressure for test CV01 and CV02 during the first $100 \mathrm{~h}$. 


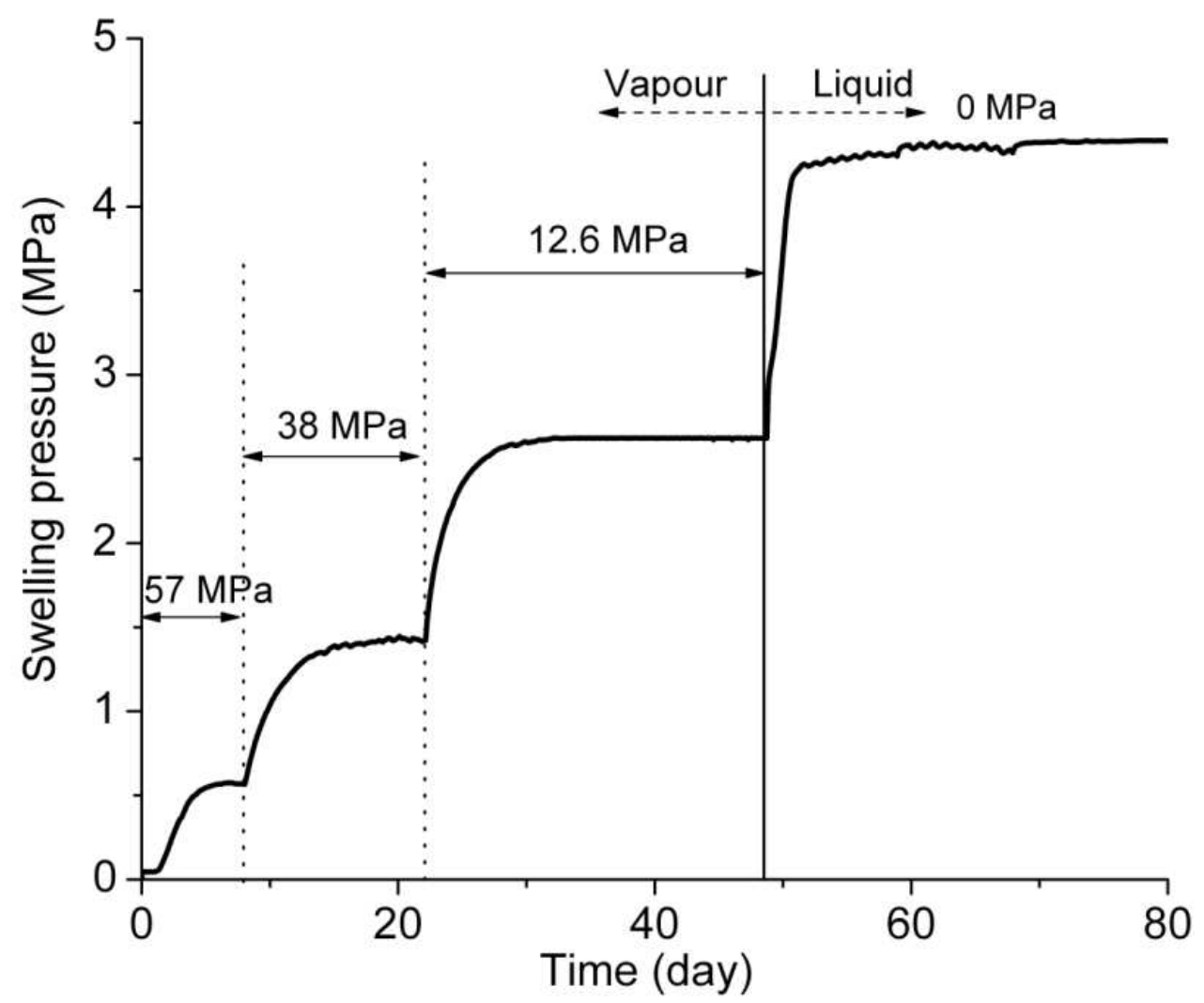

Figure 6. Evolution of swelling pressure for test CV03 during decreasing of suction.

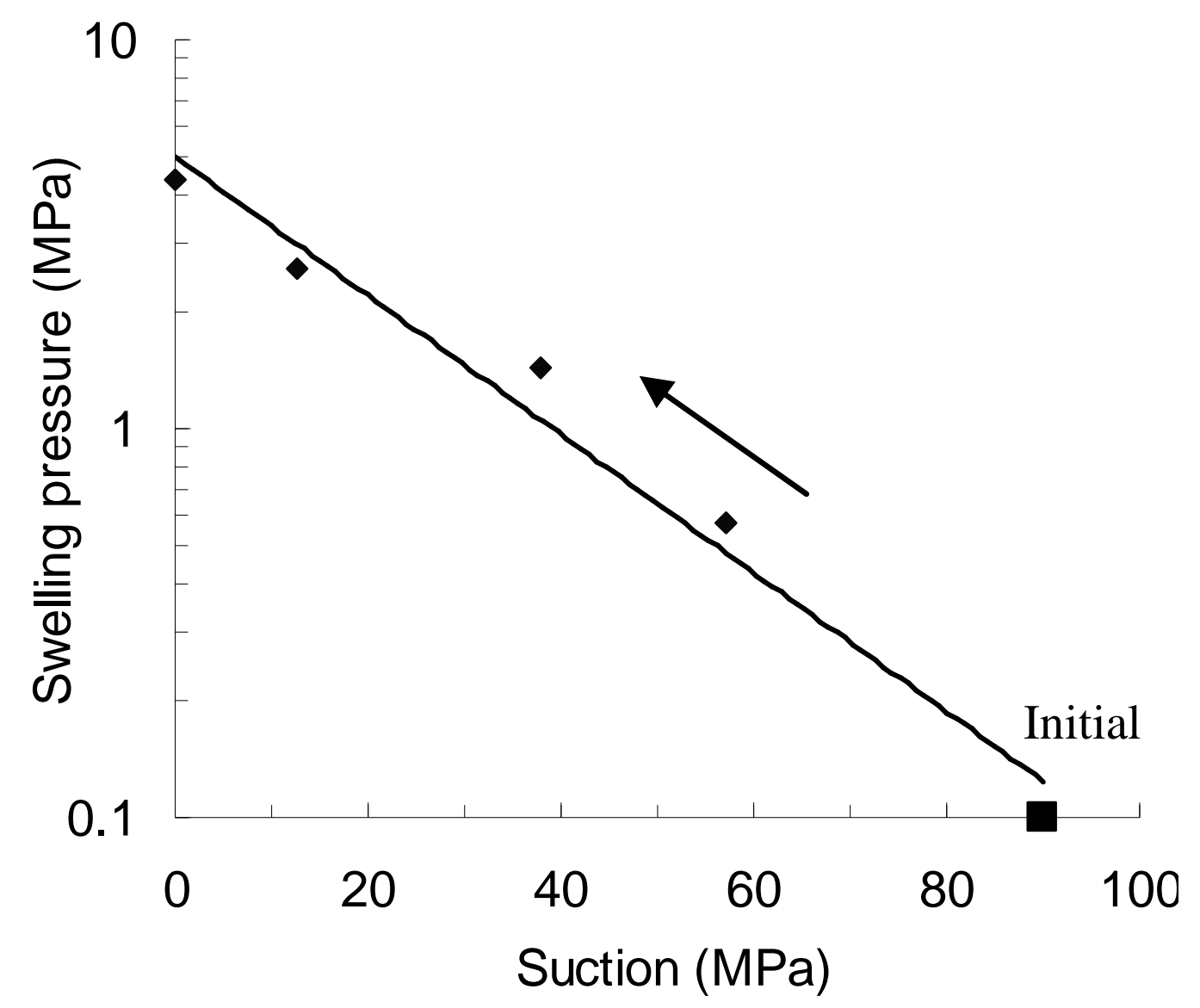

Figure 7. Swelling pressure versus suction of test CV03 


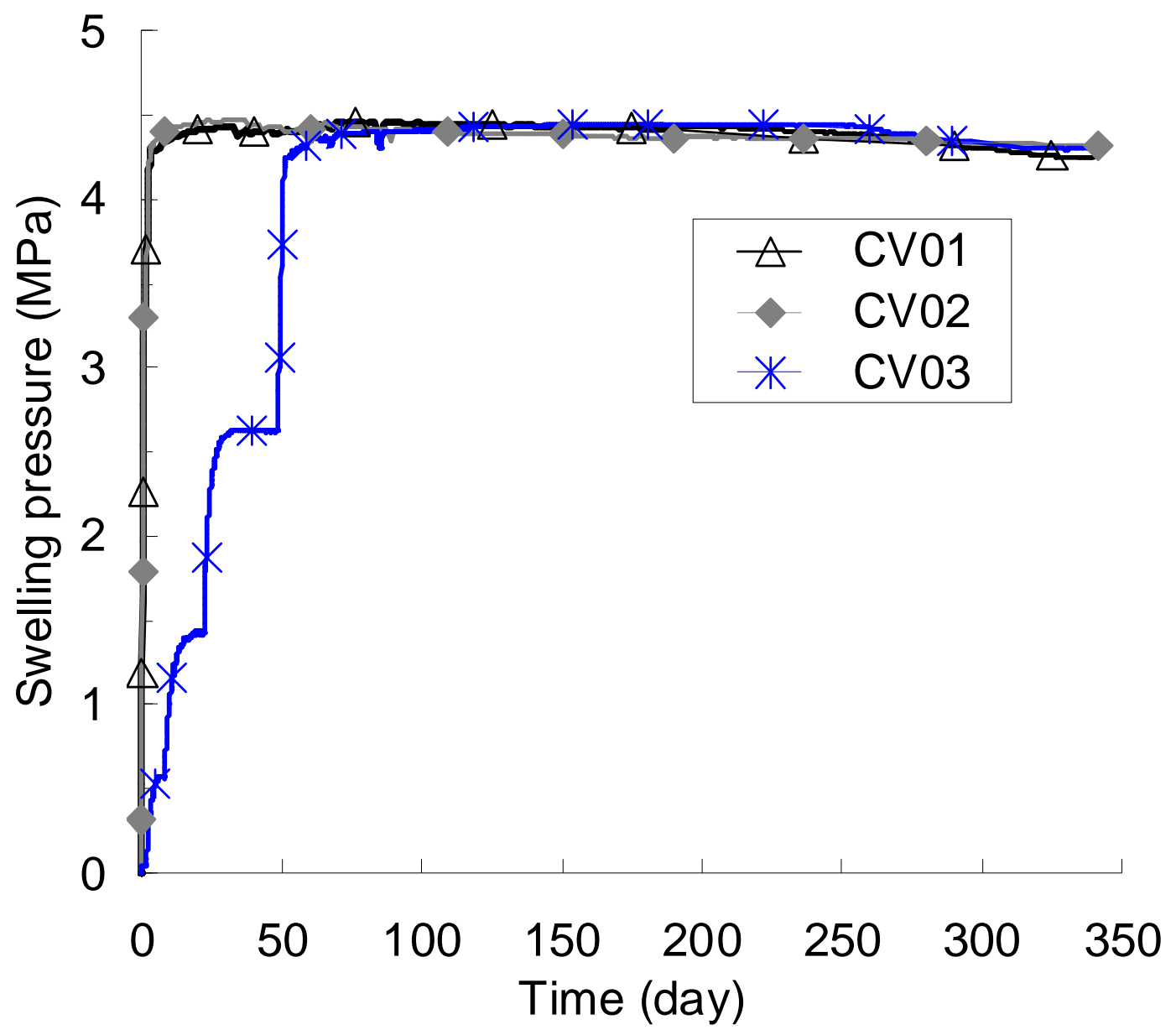

Figure 8. Evolution of swelling pressure for tests CV01, CV02, and CV03 for 1 year 


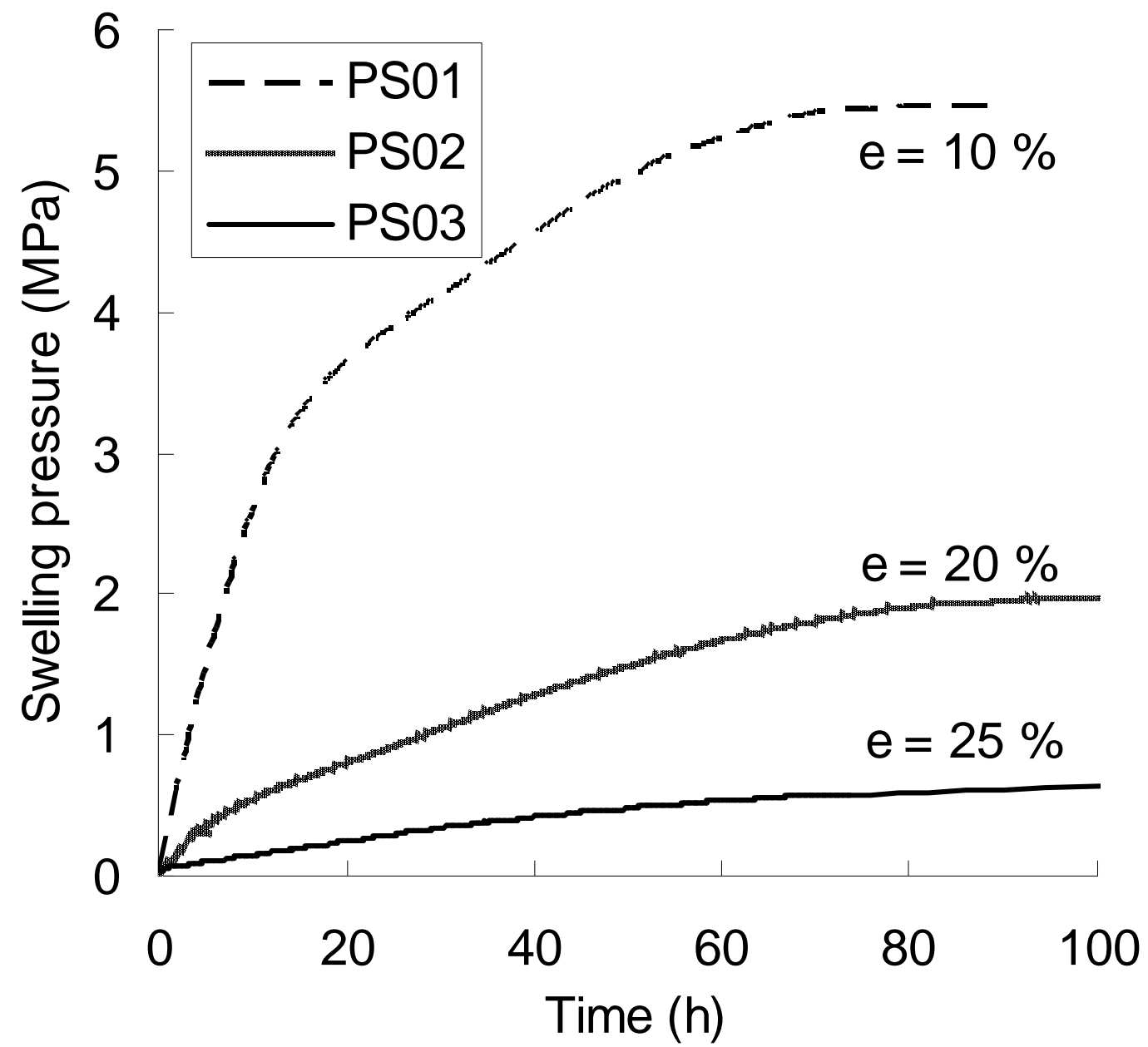

Figure 9. Evolution of swelling pressure with various pre-swells 


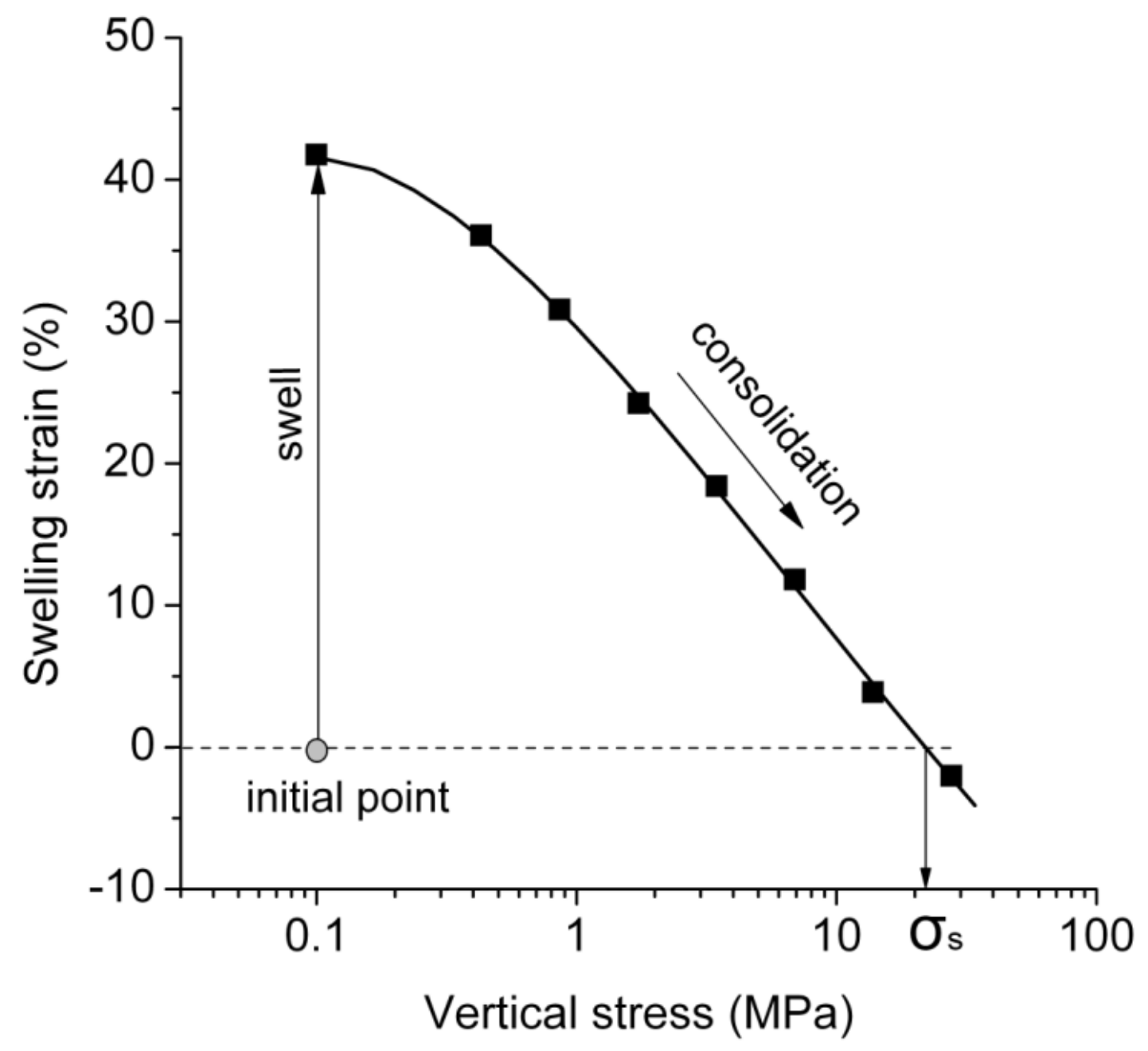

Figure 10. Swelling strain versus vertical stress applied for test SCO1 


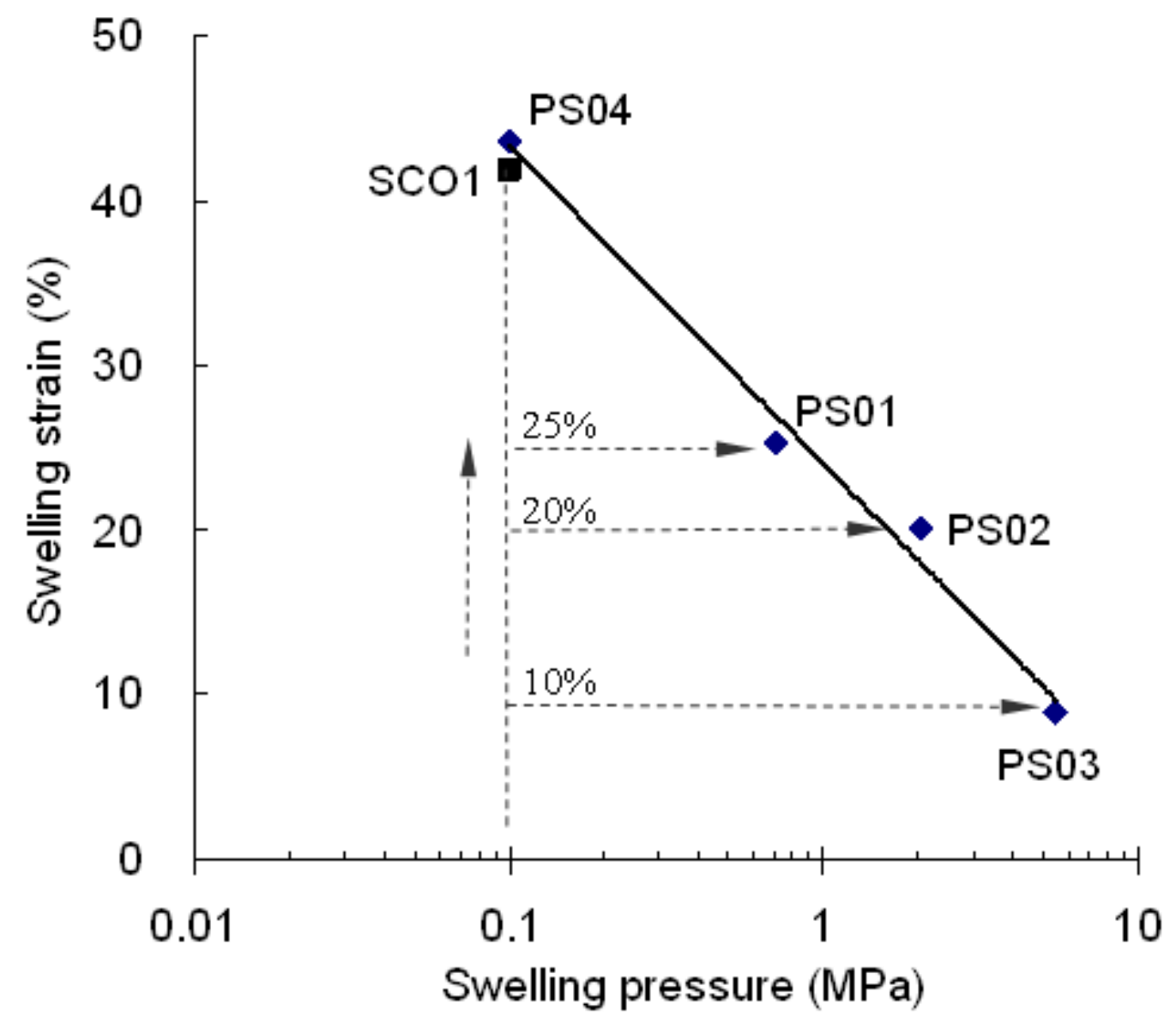

Figure 11. Pre-swell versus swelling pressure 


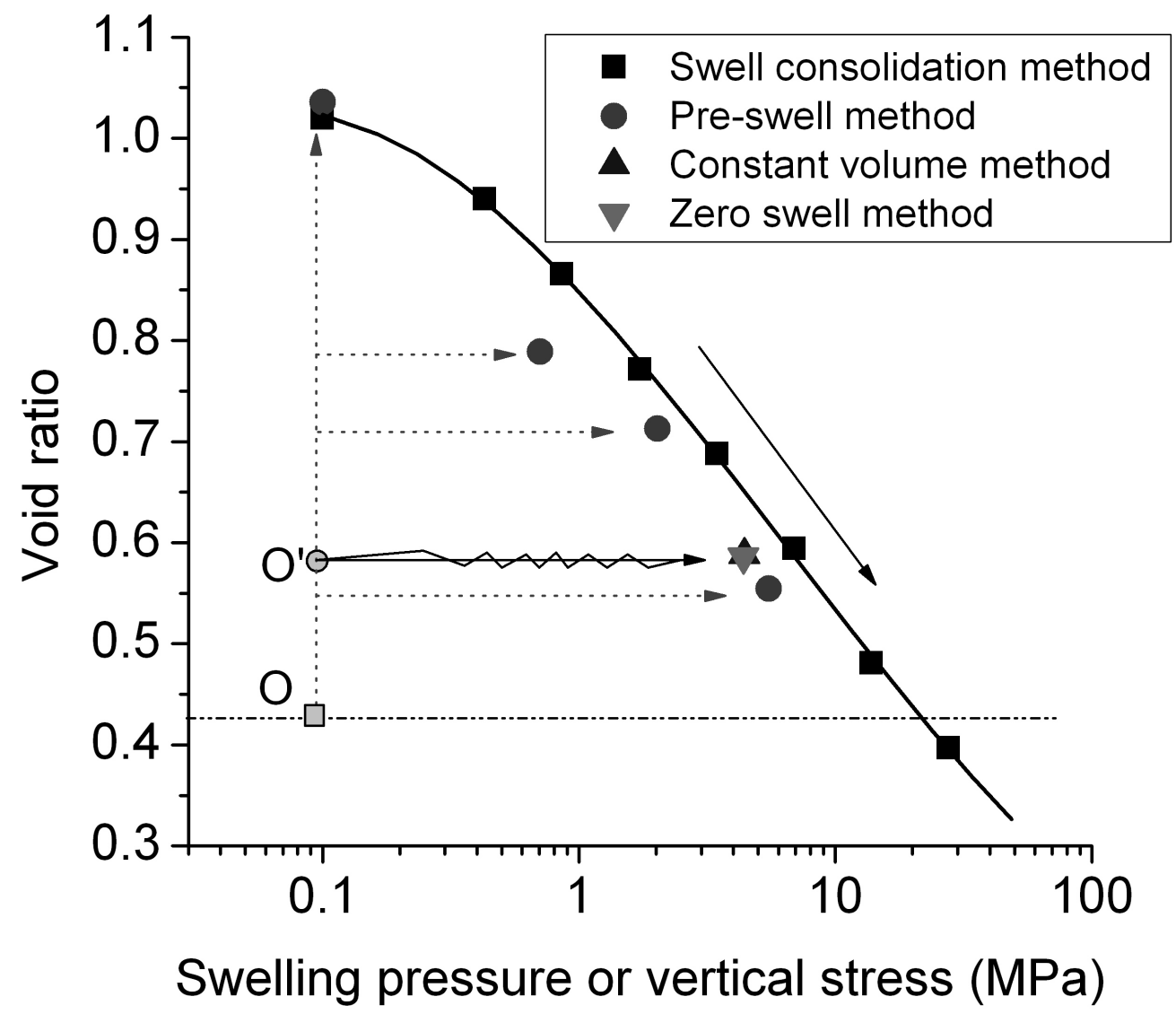

Figure 12. Swelling pressure or vertical pressure versus void ratio of mixture 


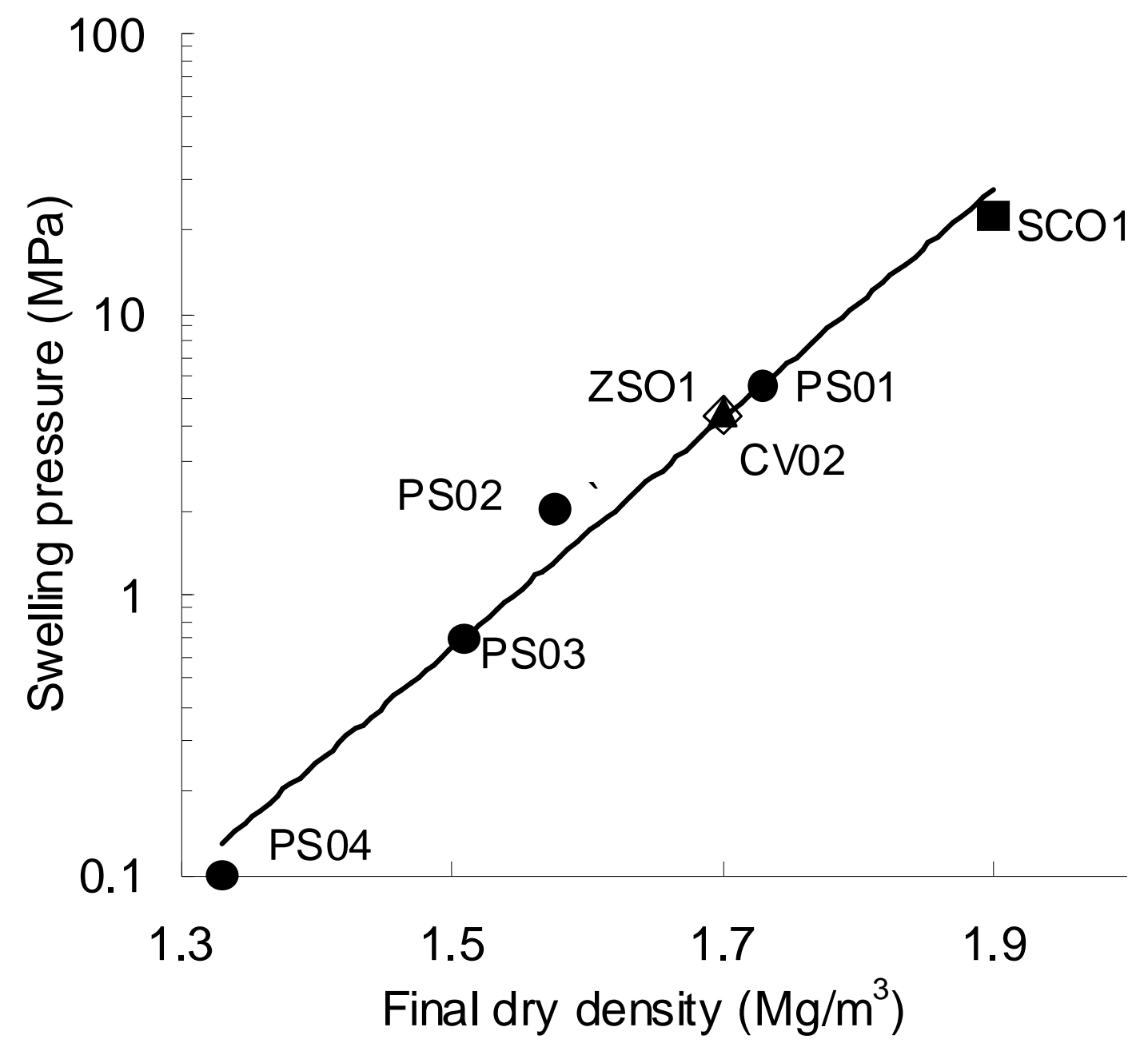

Figure 13. Swelling pressure versus finial dry density of bentonite/claystone mixture 


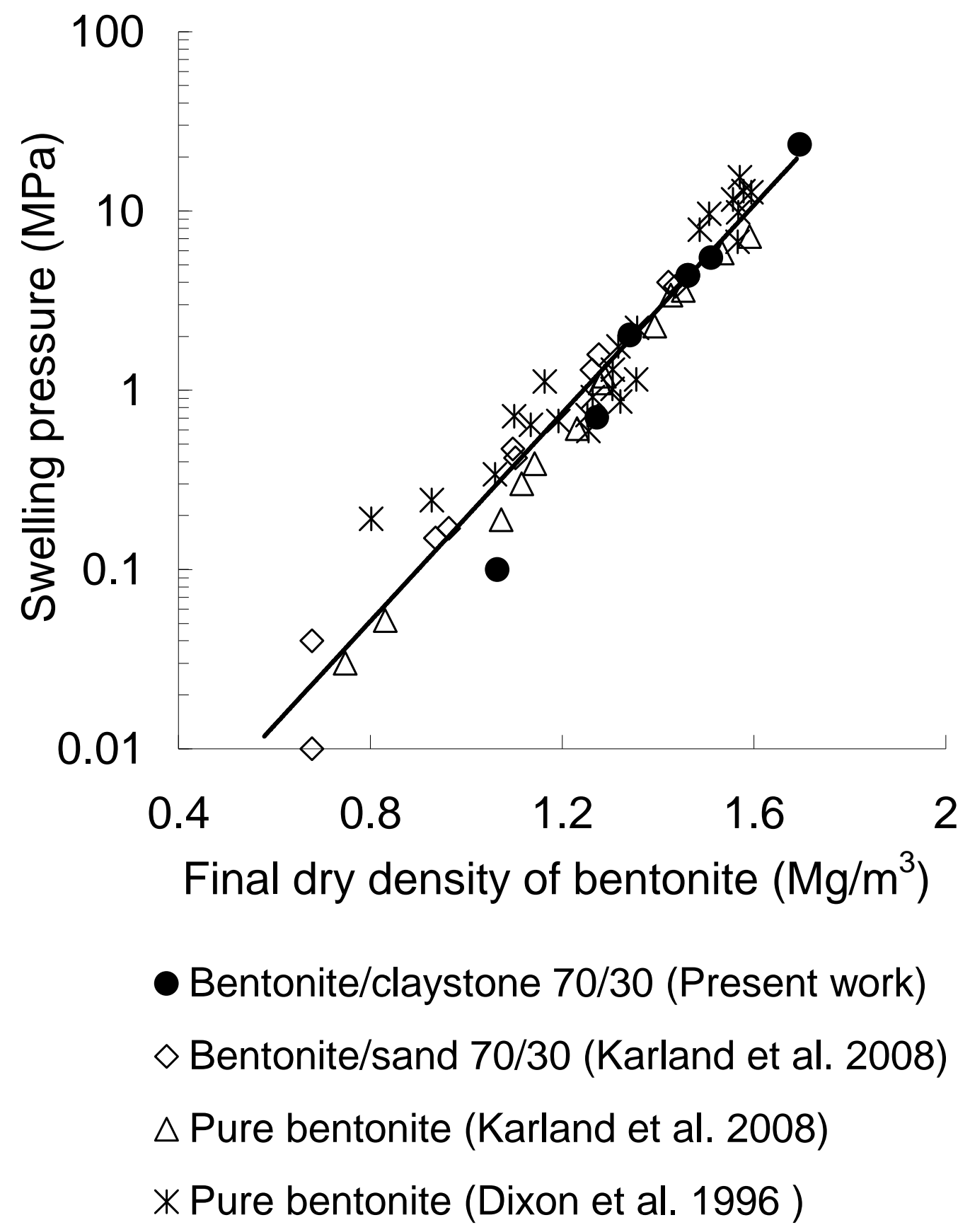

Figure 14. Results of various mixtures using MX80 bentonite - swelling pressure versus final dry density of bentonite 


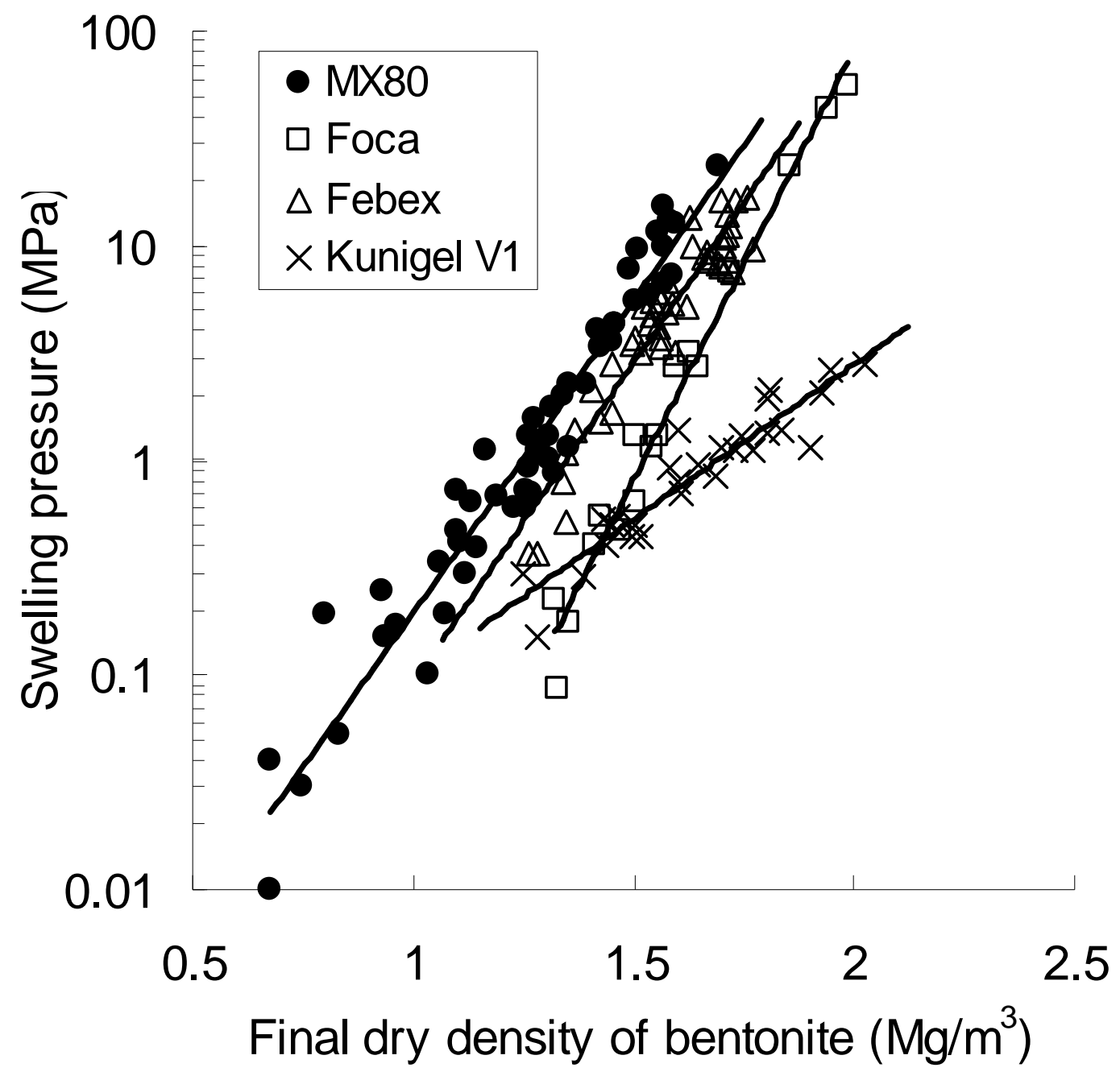

Figure 15. Swelling pressure versus final dry density of bentonite 